\title{
Antifungal and antibacterial properties of surfactin isolated from Bacillus subtilis growing on molasses
}

\author{
G.A. Płaza ${ }^{1,2 \star}$, A. Turek ${ }^{1}$, E. Król ${ }^{3}$ and R. Szczygłowska ${ }^{4}$ \\ ${ }^{1}$ Institute for Ecology of Industrial Areas, Department of Environmental Microbiology, 40-844 Katowice, Poland. \\ ${ }^{2}$ Silesian University of Technology, Department of Environmental and Safety Management, 41-800 Zabrze, 66, De \\ Gaulle, Poland. \\ ${ }^{3}$ University of Life Sciences, Department of Phytopathology and Mycology, 20-069 Lublin, Poland. \\ 4"Strzegowa" Water Company, Research Accredited Laboratory, 63-500 Ostrzeszów, Piastowska 105, Poland.
}

Accepted 10 May, 2013

\begin{abstract}
The aim of the study was to evaluate antifungal and antibacterial properties of surfactin isolated from Bacillus subtilis growing on molasses. Molasses replaced the traditional microbiological media to culture the $B$. subtilis. 10 phytopathogens and $30 \mathrm{E}$. coli strains were used in the study. The results demonstrated the ability of surfactin produced by Bacillus sp. growing on molasses to inhibit mycelial growth of the 4 fungi from 10 tested and all $E$. coli strains measured by agar plate inhibition assays. Fungi inhibited to the greatest degree as measured by the inhibition zones were Botrytis cinerea A 258 ( $50 \%$ of inhibition), Sclerotinia sclerotiorum K 2291 ( $50 \%$ of inhibition), Colletotrichum gloeosporioides A 259 ( 40\% of inhibition), Phoma complanata A 233 ( 38\% of inhibition), Phoma exigua var. exigua A 175 ( $20 \%$ of inhibition). Among the E. coli, high inhibition growth was noted in $76 \%$ of the isolates. Application of natural products such as biosurfactant may be a new approach to biological control therefore reducing the need for synthetic chemical compounds.
\end{abstract}

Key words: Phytopathogens, Escherichia coli, Bacillus subtilis, surfactin, biocontrol, phytopathogens, biosurfactant.

\section{INTRODUCTION}

Gram-positive bacteria, including Bacillus spp., produce a variety of antibacterial and antifungal metabolites, antibiotics such as zwittermicin-A and kanosamine and cyclic lipopeptides (LPs) from the surfactin, iturin and fengycin families (Emmert and Handelsman, 1999; Jacobsen et al., 2004; Ongena and Jacques, 2007). Cyclic lipopeptides have well potential in biotechnological applications because of their biosurfactant properties. Biosurfactants have numerous beneficial qualities including non-toxic, non-hazardous, biodegradable, environmental friendly, selective, effective under extreme conditions, numerous industrial applications, and unique surface-active properties. In spite of these beneficial properties, their higher production cost compared to synthetic surfactants is a major drawback. Biosurfactants could potentially replace synthetic surfactants if cost of production was lowered substantially. One of the ways to reduce substrate cost for biotechnology at present is to use recycled agricultural wastes at the right balance and high concentrations of nutrients to support microbial growth and biosurfactants production.

So far, several renewable substrates including various 
Table 1. Selected parameters of molasses as medium for Bacillus growth.

\begin{tabular}{lcc}
\hline Parameter & Unit & Molasses \\
\hline $\mathrm{pH}$ & & 7,65 \\
$\mathrm{COD}$ & $\mathrm{mgO}_{2} / \mathrm{L}$ & 49075 \\
$\mathrm{BOD}_{5}$ & $\mathrm{mgO}_{2} / \mathrm{L}$ & 25060 \\
Water content & $\%$ & 17,75 \\
Organic matter & $\%$ & 82,15 \\
Sucrose & $\%$ & 51,25 \\
Aminoacids & $\%$ & 5,5 \\
Total N & $\%$ & 1,94 \\
\hline
\end{tabular}

agricultural and industrial by-products and waste materials have been intensively studied for microorganism cultivation and biosurfactant production on the laboratory scale. These include olive oil mill effluent, waste frying oil, oil refinery wastes, soapstock, molasses, whey, starch wastes, cassava-flour processing effluent and distillery waste (Deleu and Paquot, 2004; Makkar and Cameotra, 2002). Value added products or benefits can improve the economics of such bioprocesses including microbial waste reduction. In our study, the antifungal and antibacterial properties of surfactin produced by Bacillus subtilis cultured on molasses were assessed.

\section{MATERIALS AND METHODS}

\section{Microbial strains}

The bacterial strain named $T^{\prime}-1$ used in this study were isolated from 100-year-old oil refinery sludge in Czechowice-Dziedzice (Poland) as described by Berry et al. (2006). The isolate was identified on the previous study by the following method: 16S rRNA gene sequence analysis, fatty acids analysis (FAME) and BIOLOG ${ }^{\mathrm{TM}}$ system (Płaza et al., 2012). The fungal plant pathogens originated from the collection of the Department of Phytopathology and Mycology, University of Life Sciences in Lublin. They were previously isolated from various parts of caraway (Sclerotinia sclerotiorum K2291, Phomopsis diachenii K 657, Septoria carvi K 2082, Colletotrichum dematium K 425), angelica (Botrytis cinerea A 258, Colletotrichum gloeosporioides A 259, Phoma complanata A 233, Phoma exigua var. exigua $A$ 175) and grapevines (Phomopsis viticola W 977, Rhizoctonia solani W 70). Their taxonomic position was based on macro- and microscopic features and pathogenicity tests (Machowicz-Stefaniak et al., 2011). Majority of these pathogens can infect a lot of plant species but some of them such as Phomopsis viticola, Septoris carvi and Phomopsis diachenii infect only one host or a few species within the same botanical family. Moreover, the studied strains represented both soil pathogens and above-ground plant pathogens. Bacteria Escherichia coli were isolated from the raw effluents from the wastewater treatment plant according to EN ISO 9308-1:2000.

\section{Culture conditions for isolation of biosurfactant}

Bacterial suspensions of $B$. subtilis, obtained from a nutrient agar slant incubated for $24 \mathrm{~h}$ at $30^{\circ} \mathrm{C}$, in the liquid Standard Methods medium of the following composition $\left(\mathrm{g} \mathrm{x} \mathrm{cm}^{-3}\right)$ : peptone -8 , yeast extract -2.5 , glucose -1 were adjusted to OD600nm 0.65 (ca. 107-
$108 \mathrm{CFU} \times \mathrm{dm}^{-3}$ ). Then, three $\mathrm{ml}$ of the bacterial suspension was inoculated in $300 \mathrm{ml}$ Erlenmeyer flasks containing $100 \mathrm{ml}$ of the sterilized $10 \%(\mathrm{v} / \mathrm{v})$ of molasses as nutrients sources. The characteristics of the molasses are presented in Table 1. The cultures were grown aerobically at $30^{\circ} \mathrm{C}$ for $96 \mathrm{~h}$ with constant shaking $(110$ rpm). After incubation, the cultures were centrifuged at $10000 \mathrm{~g}$ for $20 \mathrm{~min}$. Then, the supernatants were used to isolate biosurfactant.

\section{Isolation of surfactin}

Biosurfactant was isolated as described Joshi et al. (2008). Biosurfactant was precipitated by adjusting the $\mathrm{pH}$ of the cell-free supernatant to 2.0 using concentrated $\mathrm{HCl}$, then the acidified supernatant was stored overnight at $4^{\circ} \mathrm{C}$. The precipitate was centrifuged at $9000 \mathrm{~g}$ for $15 \mathrm{~min}$. Then, the biosurfactant pellet was suspended in the redistilled water and adjusted to $\mathrm{pH} 7.0$ using $2 \mathrm{~N} \mathrm{NaOH}$. The surfactin concentration was expressed as described by Sheppard and Mulligan (1987).

\section{In vitro antagonism experiment}

Biosurfactant isolated from Bacillus $s p$. were tested for the ability to inhibit the growth of fungal plant pathogens in Petri dishes on potato dextrose agar (PDA) medium as described by Velmurugan et al. (2009) with some modifications. $200 \mu \mathrm{l}$ of the surfactin solution were added drop by drop in wells made with a sterile cork borer at 1 $\mathrm{cm}$ diameter in gelified medium. Fungal growth inhibition was evaluated after plate incubation at $25^{\circ} \mathrm{C}$ for 3 or 10 days, depending on the pathogens growth. Sterilized molasses was used as the controls. Antifungal index (mycellial growth inhibition) was calculated as the follows:

antifungal index $(\%)=\left(1-\frac{A}{B}\right) * 100 \%$

where, $\mathrm{A}=$ diameter of fungal growth in the treatment samples $\mathrm{B}=$ diameter of fungal growth in the controls

The ability to inhibit the growth of $E$. coli isolates by biosurfactant was performed in Petri dishes on standard method agar (SMA) medium. $200 \mu \mathrm{l}$ of the surfactin were dispensed in wells made with a sterile cork borer at $1 \mathrm{~cm}$ diameter in the centre of gelified medium. The critical micelle concentration (CMC) value determined according to the method described by Sheppard and Mulligan (1987), was $0.127 \mathrm{mg} /$ liter. The isolates from the solid medium were inoculated around the wells. Bacterial growth inhibition was evaluated after plate incubation at $37^{\circ} \mathrm{C}$ by $48 \mathrm{~h}$. The experiments were carried out in triplicate.

\section{RESULTS AND DISCUSSION}

Currently, the main drawback for the widespread use of biosurfactants is the disadvantageous economics of their production. Biosurfactants could potentially replace synthetic surfactants if cost of their production is lowered substantially. Achieving this goal requires finding alternative inexpensive substrates and highly efficient microorganisms for biosurfactant production. The choice of inexpensive raw materials is important to the overall economics of the process because they account for $50 \%$ of the final product cost. The best way to reduce substrate cost for biotechnology at present is to use wastes 
Płaza et al.

Table 2. Effect of surfactin on tested phytopathogens.

\begin{tabular}{lc}
\hline Phytopathogen & Percentage (\%) inhibition \\
\hline Botrytis cinerea A 258 & $51,03 \pm 2,04$ \\
Rhizoctonia solani W 70 & $16,67 \pm 1,23$ \\
Sclerotinia sclerotiorum K 2291 & $52,42 \pm 0,88$ \\
Phomopsis diachenii K 657 & 0,00 \\
Phomopsis viticola W 977 & $7,14 \pm 1,22$ \\
Septoria carvi K 2082 & 0,00 \\
Colletotrichum dematium K 425 & 0,00 \\
Colletotrichum gloeosporioides A 259 & $45,06 \pm 2,45$ \\
Phoma complanata A 233 & $38,33 \pm 0,97$ \\
Phoma exigua var. exigua A 175 & $20,27 \pm 1,01$ \\
\hline
\end{tabular}

with the right balance of carbohydrates and lipids to support optimal bacterial growth and biosurfactants production, and which are either free and carry a cost credit for environmental benefit (Makkar and Cameotra, 2002). As known, millions of tons of hazardous and non-hazardous wastes are generated each year throughout the world. There is a great need for better management of these wastes via the concept: reduce, reuse, and recycle (Makkar and Cameotra, 2002).

The 16S rRNA gene sequencing could not clearly assign isolate T'-1 to any species of Bacillus as isolate showed $>99 \%$ similarity to two distinct species $B$. subtilis and Bacillus amyloliquefaciens. The metabolic profile of 94 biochemical tests as measured by the BIOLOG TM system, showed identification matches for $B$. subtilis ss spizenii with SIM value of 0.567 utilizing 68 substrates. However, FAME analysis showed that this strain was $B$. subtilis. The results identified that the surface active properties of free-cell supernatant were the best when bacteria grew on molasses. Replacing traditional microbiological media with agro-industrial wastes as substrates for biosurfactant production holds great potential. Moreover, this will reduce many management problems of processing industrial waste and cost of biosurfactant production.

Among the potential biosurfactant-producing microbes, Bacillus species are known to produce cyclic lipopeptides including surfactins, iturins, fengycins and lichenysins as the major classes of biosurfactants (Jacques, 2011; Perez-Garcia et al., 2011). Surfactin, one of the most effective surfactants produced by Bacillus strains showed a ST of $25 \mathrm{mN} / \mathrm{m}$, an IT $<1.0 \mathrm{mN} / \mathrm{m}$ and CMC of $0.025 \mathrm{~g}$ $x \mathrm{dm}-3$. Poliwoda et al. (2012) characterized the biosurfactant produced by T'- 1 isolate cultured on molasses as surfactin. In Table 2 and Figure 1, antifungal activities of the surfactin are presented. Fungi inhibited to the greatest degree as measured by the inhibition zones were Botrytis cinerea A 258 ( $50 \%$ of inhibition), Sclerotinia sclerotiorum K 2291 ( 50\% of inhibition), Colletotrichum gloeosporioides A 259 ( 40\% of inhibition), Phoma complanata A 233 ( $38 \%$ of inhibition), Phoma exigua var. exigua A 175 ( $20 \%$ of inhibition). In previous work, the antifungal property of different surfactants - Rokamin K30, Rokamin SR5, Sulforokanol L270/1, SDS, Tergitol 15-S-7, Tween 80, natural surfactant - saponin and cellfree supernatant from $B$. subtilis growing on agro-industrial wastes were evaluated (Płaza et al., 2012). The results showed that surfactant like Rokamin K30, Rokamin SR5, Sulforokanol L270/1 inhibited mycelial growth two times more strongly than other chemical surfactants. Compared with the chemical surfactants, culture-free supernatant was more active than saponin, Tween 80 and sodium deodecyl sulphate (SDS).

On the other hand, among the $E$. coli isolates high inhibition caused by surfactin was noted (Table 3 and Figure 2). Ghribi et al. (2012) evaluated the antimicrobial activity of the biosurfactant produced by $B$. subtilis SPB1 growing on traditional microbiological medium against bacteria, fungi and yeast. The biosurfactant produced by $B$. subtilis SPB1 was characterized by an important antifungal activity, especially, against Penicillium notatum, Penicillium italicum, and Aspergillus niger and lower activity against Rhizopus oryzae and Aspergillus oryzae. This activity was clearly negative against Alternaria alternata, Puccinia allii and Peronospora destructor. Moreover, it was clear that this compound presented also an important antiyeast activity, mainly, against Candida albicans. The compound showed important antimicrobial activity against microorganisms with multidrug-resistant profiles. Its activity was very effective against Staphylococcus aureus, Staphylococcus xylosus, Enterococcus faecalis, Klebsiella pneumonia. The compound showed also higher activity against Grampositive bacteria than against Gram-negative bacteria.

Bacteria of the genus Bacillus are known as producers of different number of secondary metabolites with the properties against bacteria, fungi and yeast growing on traditional microbiological media (Ongena et al., 2007; Arguelles-Arias et al., 2009; Perez-Garcia et al., 2011). Jacques (2011) described four main lipopeptides families from the Bacillus species: the surfactins, the iturins, the fengycins (or plipastatins) and the kurstakins. Joshi et al. (2008) described the antifungal compound produced by $B$. subtilis $20 \mathrm{~B}$ cultured on LB medium. The growth 

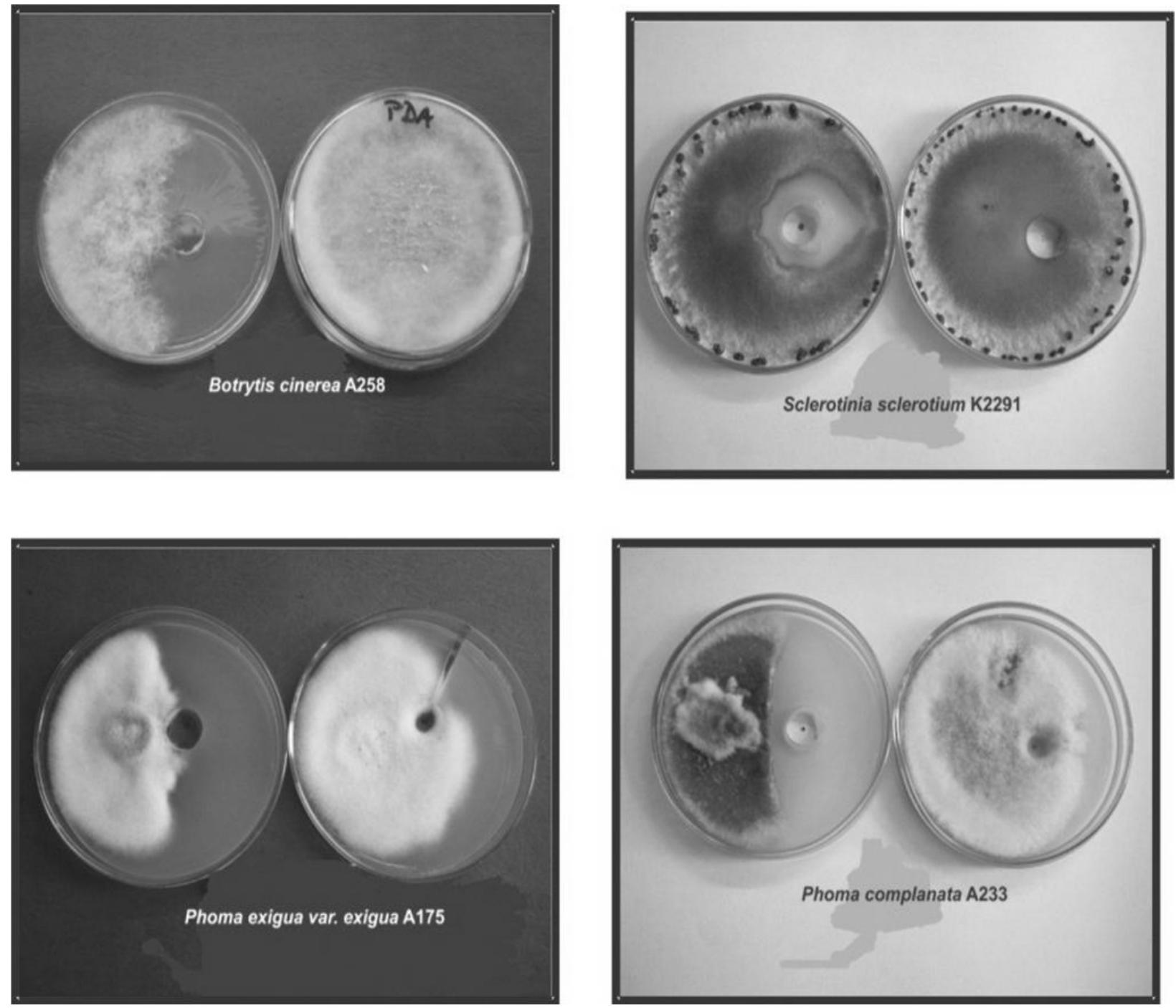

Figure 1. Growth inhibition of selected phytopathogens by surfacin ( $T^{\prime}-1$ isolate cultured on molasses). Left side, surfactin; right side, control.

inhibition of Chrysosporium indicum, Alternaria burnsii, Fusarium oxysporium, Fusarium udum, Trichoderma herzanium and Rhizoctonia bataticola was observed. Whereas, no inhibition of Aspergillus niger and Penicillium chrysogenum was observed. B. subtilis producing iturin $A$ and surfactin was shown to be effective for the control of damping-off caused by $R$. solani in tomato plants (Asaka and Shoda, 1996). Ongena et al. (2005) describe the ability of $B$. subtilis strain GA1 to protect wounded apple fruits against grey mould disease caused by Bacillus cinerea. Treatment with endospores and vegetative cells from the strain GA1 was evaluated. The results confirm the potential of $B$. subtilis species for the control of post-harvest diseases for other fruits (Perez-Garcia et al., 2011).

The toxicity of iturins to fungi has been found to rely on their ability to permeate membranes (Jacques, 2011). Also, fengycins have fungitoxic activity but more speci- fically against filamentous fungi. The fengycins action is less known compared to the other lipopeptides. Several studies present that lipopeptides are co-produced and active in synergistic way, for example surfactin with iturin, surfactin with fengycin and iturin with fengycin (Jacques, 2011; Ongena et al., 2007). Some of these species have more than antifungal properties, they have also antibacterial activity (Basurto-Cadena et al., 2012; Chen et al., 2012; Ghribi et al., 2012). Our results indicate that biosurfactant identified as surfactin produced by Bacillus strain cultured on molasses is capable of antifungal and antibacterial activities against a wide variety of phytopathogenic fungi and $E$. coli bacteria.

\section{Conclusions}

Most of biosurfactants applications depend on their specific properties. In addition, several biosurfactants have 
Table 3. Growth inhibition of $E$. coli isolates by surfactin produced by Bacillus $s p$. cultured on molasses $E$. coli isolates.

\begin{tabular}{|c|c|}
\hline E. coli isolate & Growth inhibition (after $48 \mathrm{~h}$ ) \\
\hline 1 & ++ \\
\hline 2 & +++ \\
\hline 3 & +++ \\
\hline 4 & +++ \\
\hline 5 & +++ \\
\hline 6 & +++ \\
\hline 7 & Lack isolates \\
\hline 8 & ++ \\
\hline 9 & +++ \\
\hline 10 & +++ \\
\hline 11 & +++ \\
\hline 12 & + \\
\hline 13 & ++ \\
\hline 14 & +++ \\
\hline 15 & +++ \\
\hline 16 & ++ \\
\hline 17 & +++ \\
\hline 18 & ++ \\
\hline 19 & +++ \\
\hline 20 & +++ \\
\hline 21 & +++ \\
\hline 22 & +++ \\
\hline 23 & +++ \\
\hline 24 & +++ \\
\hline 25 & + \\
\hline 26 & +++ \\
\hline 27 & +++ \\
\hline 28 & +++ \\
\hline 29 & +++ \\
\hline 30 & +++ \\
\hline
\end{tabular}

"+++", High inhibition of the bacterial growth; "++", moderate inhibition; "+", low inhibition.

been reported to have manifold biological activities like antibiotics, fungicides, insecticides, antiviral and antitumor agents or specific toxins and enzyme inhibitors. Developing knowledge of the biological properties is a key factor for introducing biosurfactants in high-added value products in different industries. Biosurfactants capable of suppressing pathogens and maintaining their population by competing against deleterious microorganisms could be successfully utilized as biopesticides for sustainable organic farming. The present research has importance in order to minimize the use of synthetic surfactants and fungicide, thus contributing to the environmental protection. The results here indicate that the $B$. subtilis growing on molasses produced surfactin which has antifungal and antibacterial activities. Despite possessing many commercially attractive properties and
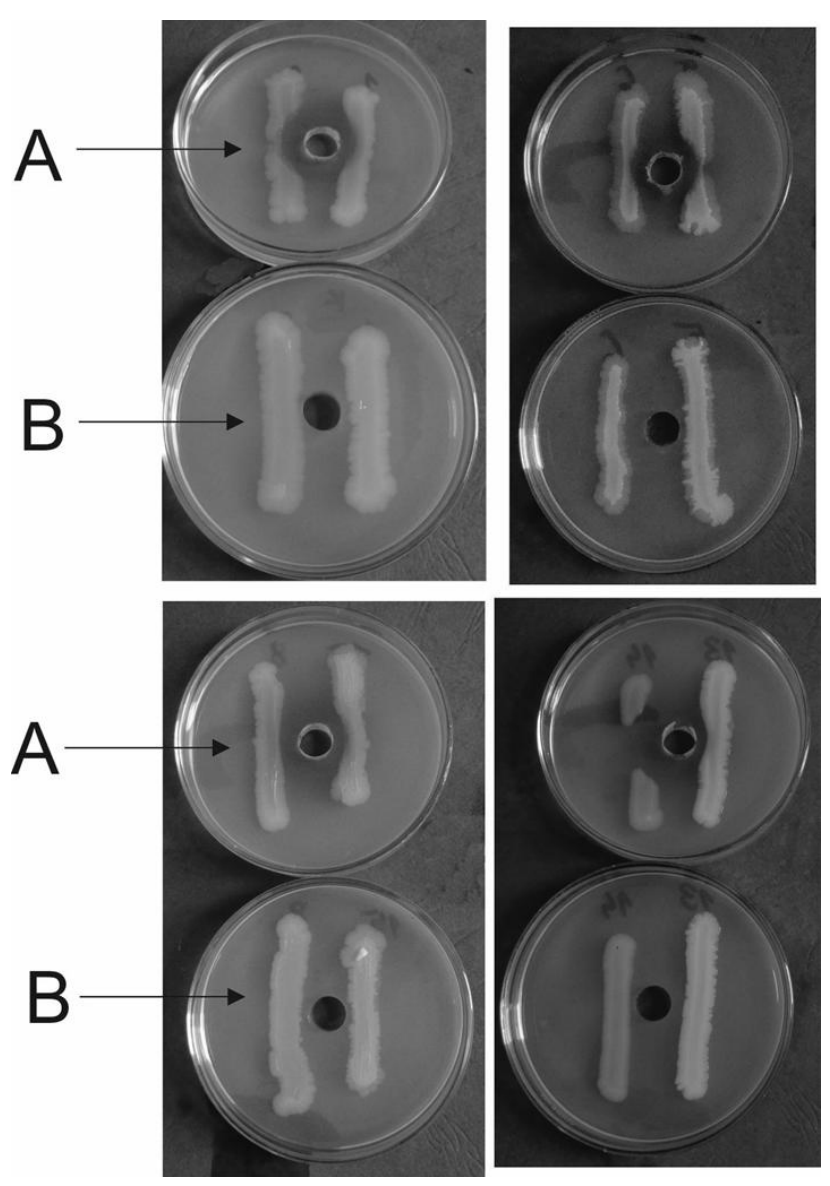

Figure 2. Growth inhibition of E. coli strains caused by surfactin produced by Bacillus T'-1 cultured on molasses; A - surfactin; B - control.

clear advantages compared with their synthetic counterparts, the production of microbial surfactants on a commercial scale up to now has not been realized because of their low yields and high production costs. One of the strategy is to use cheaper and waste substrates to lower the initial raw material costs involved in the biosurfactant production.

\section{ACKNOWLEDGEMENT}

This work was done under the project No N N523 418237 from the Polish Ministry of Science and Higher Education.

\section{REFERENCES}

Arguelles-Arias A, Ongena M, Halimi B, Lara Y, Brans A, Joris B, Fickers $P$ (2009). Bacillus amyloliquefaciens GAI as a source of potent antibiotics and other secondary metabolities for biocontrol of plant pathogens. Microbial Cell Fact. 8: 1-12.

Asaka O, Shoda M (1996). Biocontrol of Rhizoctonia solani damping-off of tomato with $B$. subtilis RB14. Appl. Environ. Microbiol. 62: 40814085.

Basurto-Cadena MGL, Vazquez-Arista M, Garcia-Jimenez J, SalcedoHernandez R, Bideshi DK, Barboza-Corona JE (2012). Isolation of a 
new Mexican strain of $B$. subtilis with antifungal and antibacterial activities. Sci. World J., doi:10.1100/2012/384978; ID 3849

Berry CJ, Story S, Altman DJ, Upchurch R, Whitman W, Singleton W, Płaza GA, Brigmon RL (2006). In: Clayton \& Lindner (eds) Biological Treatment of Petroleum and Radiological Contaminated Soil. Innovative Approaches for the Remediation of Subsurface-Contaminated Hazardous Waste Sites: Bridging Flask and Field Scales, Oxford University Press, pp. 87-103.

Chen YC, Chiang TJ, Liang TW, Wang IL, Wang LS (2012). Reclamation of squid pen by Bacillus licheniformis TKU004 for the production of thermally stable and antimicrobial biosurfactant. Biocatal. Agric. Biotechnol. 1: 62-69.

Deleu M, Paquot M (2004). From renewable vegetables resources to microorganisms: new trends in surfactants. C.R. Chimie 7: 641-646.

Emmert EAB, Handelsman J (1999). Biocontrol of plant disease: a (Gram-) positive perspective. FEMS Microbiol. Letters 171: 1-9.

EN ISO 9308-1 (2000). Water quality - Detection an denumeration of Escherichia coli and coliform bacteria - Part 1: Membrane filtration method (ISO 9308-1:2000).

Ghribi D, Abdelkefi-Mesrati L, Mnif I, Kammoun R, Ayadi I, Saadaoui I, Maktouf S, Chaabouni-Ellouze S (2012). Investigation of antimicrobial activity and statistical optimization of $B$. subtilis SPB1 biosurfactant production in solid-state fermentation. J. Biomed. Biotechnol. doi:10.1155/2012/373682.

Jacobsen BJ, Zidack NK, Larson BJ (2004). The role of Bacillus-based biological control agents in integrated pest management systems: plant diseases. Phytopathology 94: 1272-1275.

Jacques P (2011). Surfactin and other lipopeptides from Bacillus spp. In: Soberon-Chavez (ed) Biosurfactants. From genes to applications. Springer-Verlag Berlin Heidelberg, Germany, pp 32-43.

Joshi S, Bharucha C, Desai AJ (2008). Production of biosurfactant and antifungal compound by fermented food isolate B. subtilis $20 \mathrm{~B}$. Biores. Technol. 99: 4603-4608.

Machowicz-Stefaniak Z, Zalewska E, Król E (2011). Occurrence, harmfulness and morphological structures of Colletotrichum gloeosporioides (Penz.) Sacc. (teleomorph: Glomerela ingulate (Stonen) Spauld et Schrenk). Acta Sci. Pol. Hortorum Cultus 10: 39 52.
Makkar RS, Cameotra SS (2002). An update on the use of unconventional substrates for biosurfactant production and their new applications. Appl. Microbiol. Biotechnol. 58: 428-434.

Ongena $M$, Jacques $P$, Toure $Y$, Destain $J$, Jabrane A, Thonart $P$ (2005). Involvement of fengycin-type lipopeptides in the multifaceted biocontrol potential of B. subtilis. Appl. Microbiol. Biotechnol. 69: 2938.

Ongena M, Jacques $P$ (2007). Bacillus lipopeptides: versatile weapons for plant disease biocontrol. Trends Microbiol. 16: 115-125.

Ongena M, Jourdan E, Adam K, Paquot M, Brans A, Joris B, Arpigny JL, Thonart P (2007). Surfactin and fengycin lipopeptides of $B$. subtilis as elicitors of induced systemic resistance in plants. Environ. Microbiol. 9: 1084-1090.

Perez-Garcia A, Romero D, Vicente de A (2011). Plant protection and growth stimulation by microorganisms: biotechnological applications of Bacilli in agriculture. Curr. Opin. Biotechnol. 22: 187-193.

Płaza GA, Pacwa-Płociniczak M, Piotrowska-Seget Z, Brigmon R (2012). Characterization of Bacillus strains producing biosurfactants. Environmental Microbiology \& Biotechnology in the frame on the knowledge-based bio \& Green economy-EMB2012, (subsession 8.2), Bolon, Włochy, Italy.

Poliwoda A, Krzosok E, Wieczorek PP, Kafarski P, Płaza G (2012). Isolation and characterization of potential biosurfactants produced by Bacillus strains growing on agroindustrial wastes. Environ. Eng. Manage. J. 11: S80.

Sheppard JD, Mulligan CN (1987). The production of surfactin by $B$. subtilis grown on peat hydrolysate. Appl. Microbiol. Biotechnol. 27: 110-116.

Velmurugan N, Choi MS, Han SS, Lee YS (2009). Evaluation of antagonistic activities of $B$. subtilis and Bacillus licheniformis against wood-staining fungi: in vitro and in vivo experiments. J. Microbiol. 47(3): 385-392. 